\title{
Evolution, Strategies and Problems of Poverty-Alleviating Agricultural Policies and Programmes in Nigeria
}

\author{
Rosemary I. Eneji, Fidelis Akwaji \\ Department of Sociology, University of Calabar, Calabar, Nigeria \\ Email: rieneji2@yahoo.com
}

How to cite this paper: Eneji, R. I., \& Akwaji, F. (2018). Evolution, Strategies and Problems of Poverty-Alleviating Agricultural Policies and Programmes in Nigeria. Advances in Applied Sociology, 8, 699-720. https://doi.org/10.4236/aasoci.2018.812042

Received: November 5, 2018

Accepted: December 18, 2018

Published: December 21, 2018

Copyright (C) 2018 by authors and Scientific Research Publishing Inc. This work is licensed under the Creative Commons Attribution International License (CC BY 4.0).

http://creativecommons.org/licenses/by/4.0/

Open Access

\begin{abstract}
According to the UNDP (2001) report, Nigeria started its independent nationhood in 1960 with poverty level of only $15 \%$ of population, but it is today struggling to reduce it from about $70 \%$ of its current population of about 190 million. This is in spite of the fact that the country is richly endowed with numerous natural, especially agricultural and mineral resources. Nigeria's rising extreme poverty numbers are a direct result of years of negligent and ineffective government policies. Over-dependence on oil for years and an inability to generate non-oil revenue has led it to this. The country's agricultural policy aims at reaching self-sustaining growth in the agricultural sector as well as the structural transformation required for the overall socio-economic development and improvement in the quality of life of Nigerians. The key feature of the policy is the evolution of strategies for ensuring self-sufficiency and the improvement of the technical and economic efficiency in food production. This is to be achieved through the introduction and adoption of improved seeds and seed stock, husbandry and appropriate machinery and equipment, efficient utilization of resources, encouragement of ecological specialization and recognition of the roles and potentials of small-scale farmers as the main drivers of food production in the country. Nigeria's agricultural policy framework has evolved in a way that reflected, in a historical perspective, the changing character of agricultural development problems and the roles which different segments of the society were expected to play in addressing these problems. The form and direction of agricultural policy were dictated by the philosophical stance of government on the content of agricultural development and the role of government in the development process. Here, we examined Nigeria's agricultural policy evolution from the colonial to the contemporary period. The very survival of Nigeria is tied to the ability of its economy to meet the material demands of its citizens since welfare con-
\end{abstract}


stitutes a third objective of modern government. Food is an essential component of welfarism. The Nigerian Government and public policy makers must therefore see food as a component of welfarism and as such develop and sustain sufficient political will to achieve increased food production, a credible food policy and ultimately degrade poverty significantly.

\section{Keywords}

Agricultural Policy, Nigeria, Poverty, Welfare

\section{Introduction}

Agriculture was the main stay of the Nigerian economy long before the discovery of oil in commercial quantity in the 1950s. Covering an area of 924,000 square kilometers, Nigeria has varied ecology, ranging from the Sahel, Sudan and Guinea Savannahs in the North to the Southern rain forests-thus making it possible to produce many varieties of crops and livestock. About 75 percent of Nigeria's land is arable, more than half of which is not cultivated yet.

The country is also endowed with rich fishery resources and ample potentials for large-scale fish farming (Jude, 2009). Agriculture is still largely at rain-fed, subsistence level, characterized by smallholdings, traditional and inefficient method of cultivation, storage and processing (Olagunju, 2007). However, it is still the single largest contributor to the well-being of majority of the population, sustaining over 86 percent of rural households.

Agriculture should be the industrial and economic springboard for the nation's quest for accelerated growth and development as it is well-placed to have a high multiplier effect on the economy because of its linkages to the other real sectors of the economy. The contemporary socio-economic literature is replete with evidences of the potency of agriculture as a driver of sustained economic growth and development. The experiences of China, Brazil, Malaysia and Indonesia-countries with development characteristics similar to Nigeria, are instructive. These countries have relied on their agricultural prowess to facilitate the process of industrialization from predominantly agrarian economies (Enebeli-Uzor, 2010).

The principal export crops for Nigeria are cocoa, cotton, groundnuts, (peanuts), palm oil and rubber, which together account for nearly 60 percent of nonoil merchandise exports. Livestock also thrives in the country and they include cows, donkeys, ducks, geese, goats, chicken, guinea fowls, pigeons, pigs, sheep and turkey. The main export destinations for Nigeria's agricultural produce are the European Union, the United States and Canada. Nigeria is about the world's fourth largest producer of cocoa, and the crop is the country's second largest foreign exchange earner after crude oil; Cross River State is the second largest producer in Nigeria. Cassava is unarguably the most cultivated commodity in Nigeria-accommodating more than 40 million farmers who produce nearly 50 
million tonnes annually. The country has enormous comparative advantages in cassava production which if well harnessed could become a key driver of growth (Shinka, 2009).

Nigeria is a top producer of palm oil in the world although productivity has greatly dwindled in recent times. Rubber is another key source of export earnings, butits production has also fallen significantly. Although rice production expanded by about 50 percent year-on-year between 2000 and 2013, domestic demand is still in excess of production by more than 2 million tonnes (Enebeli-Uzor, 2010) and rice accounts for more than 25 percent of agricultural imports in Nigeria. Demand for rice in Nigeria is expected to be sustained as it has become the most popular staple food rather than the exclusive preserve of the affluent (Sanni, 2010).

Nigeria, now ranked among the poorest countries in the world, started its independent nationhood with poverty level of only $15 \%$ of its population in 1960 but is today struggling to reduce it from about $70 \%$ of its population of about 190 million. This is in spite of the fact that the country is richly endowed with all kinds of water, agricultural and mineral resources. Poverty in Nigeria is a paradox because its level appears as a contradiction considering the country's immense wealth. The North-West and North-East geo-political zones recorded the highest poverty rates in the country with $77.7 \%$ and $76.3 \%$ in 2010 , while the South-West geo-political zone recorded the lowest at 59.1\%. Among States, Sokoto had the highest poverty rate at $86.4 \%$ while Niger had the lowest at $43.6 \%$ in 2010. Poverty situation is worsened even with the huge human and material resources that have been devoted to its reduction by successive governments. Thus, about 65 percent of the population live on less than $\$ 1.00$ (one U.S. dollar) a day in purchasing power parity. Of the number of the poverty stricken people, about $75 \%$ is concentrated in the rural areas where illiteracy is high, potable water and health facilities are rarely available and road and electricity infrastructures are either unavailable or ill-managed. According to a study by Ahmed et al. (2007), while dividing the poor into ultra-poor (living on less than $\$ 0.50$ a day), medial poor ( $\$ 0.50$ - $\$ 0.75$ a day) and subjacent poor ( $\$ 0.75$ - 1 a day), Nigeria is the single largest country in sub-Saharan Africa, accounting for between 21 and 30 per cent of the number of ultra, medial and subjacent poor.

Reports from the World Poverty Clock, suggest that Nigeria's struggle with overpopulation will be a problem soon, rather than in 2050. In February 2018, Nigeria was considered to have overtaken India as the country with the most people in extreme poverty. Currently, 82 million Nigerians or 42.4 percent of the population live in extreme poverty. Nigeria's population is growing faster than its economy. Between 1990 and 2013, the population increased by 81 percent. By 2050 , going by the speed of its present population growth rate, Nigeria will be the third most populous country in the world. By passing the 400 million mark, it will be over-taking the U.S.A. and be only behind China and India.

In recent times, Nigeria's recent dwindling oil wealth due to the global oil 
price reduction has adversely affected its GDP. The country's economy was hit hard by the recent recession and the IMF projects the country's GDP to rise by only 0.8 percent in 2018 , after the recession since 2016 had slowed the economy. Nigeria's average household income per capita is $\$ 1168$ but the country's wealth is concentrated with the elites, rather than among the people. The high rate of unemployment, endemic corruption, absence of basic social amenities for millions of people, difficulty of doing business and the millions living in poverty are all consequences of the huge inequality in the country.

Nigeria's rising extreme poverty numbers is a direct result of years of negligent and ineffective government policies. Over-dependence on oil for years and an inability to generate non-oil revenue has led it to this. Nigeria's 2018 record budget is running on a deficit to be funded with much borrowing, thereby increasing government debts. The solution to this problem would be the development of a credible (agricultural) policy aimed at eradicating poverty.

\section{Agricultural Policy Objectives and Features}

Nigeria's agricultural policy includes the framework and action plans of Government aimed at achieving overall agricultural growth and development. The policy aims at reaching self-sustaining growth in the agricultural sector as well as the structural transformation required for the overall socio-economic development of the country and improvement in the quality of life of Nigerians. The policy objectives include:

1) Attainment of self-sufficiency in basic food commodities, especially those accounting for considerable shares of Nigeria's foreign exchange and for which there is considerable comparative advantage in local production;

2) Enhanced production of agricultural raw materials to satisfy the growth of an expanding industrial sector;

3) Increased production and processing of exportable commodities to boost their foreign exchange earning capacity and further diversify the Nigeria's export base and sources of foreign exchange earnings;

4) Modernization of agricultural production, processing, storage and distribution through the infusion of improved technologies and management to make agriculture more responsive to the demands of other sectors of the Nigerian economy;

5) Creation of more agricultural and rural employment opportunities to increase the income of farmers and rural dwellers while productively absorbing an increasing labour force in the country;

6) Protection, conservation and improvement of agricultural land resources and preservation of the environment for sustainable agricultural production;

7) Establishment of appropriate institutions and creation of administrative organs for the integrated development and realization of Nigeria's agricultural potentials.

The key feature of the policy is the evolution of strategies for ensuring 
self-sufficiency and the improvement of the technical and economic efficiency in food production. This is to be achieved through the introduction and adoption of improved seeds and seed stock, husbandry and appropriate machinery and equipment, efficient utilization of resources, encouragement of ecological specialization and recognition of the roles and potentials of small scale farmers as the main drivers of food production in the country. Reductions in risks and uncertainties were to be achieved through the introduction of the agricultural insurance scheme to minimise natural hazards militating against agricultural production and security of credit outlay through indemnity of sustained losses. A nationwide, unified and all-inclusive extension delivery system under the Agricultural development Programme (ADP) was put in place in a joint Federal and State Governments collaborative effort. Agro-allied industries were actively promoted. Other incentives such as rural infrastructure, rural banking, primary health care, cottage industries, etc, were provided to encourage agricultural and rural development and attract youth, including school leavers' to farmland.

The agricultural policy is supported by subsidiary policies facilitating the growth of the sector. These sub-policies cover issues of labour, capital and land whose prices affect the profitability of production systems-crops, fisheries, livestock and land use; input supply, pest control and mechanization; water resources and rural infrastructure; agricultural extension, research, technology development and transfer; agricultural produce storage, processing, marketing, credit and insurance; cooperatives, training and manpower development, agricultural statistics and information management. However, the implementation of the agricultural policy is a function of the macro-economic policies which provide the enabling environment for agriculture to grow along with the other sectors. These policies usually have major impact on the profitability of the agricultural system and the welfare of farmers as they affect the flow of funds to the sector in terms of budgetary allocation, credit, subsidies, taxes, etc. and, therefore, must be in harmony and mutually reinforcing the agricultural policy. The macro policies comprise the fiscal, monetary, trade, budgetary policies and other policies governing macro-prices.

\section{Evolution of Agricultural Policies in Nigeria}

\subsection{Colonial Era}

Nigeria's first adoption of planned agricultural development and extension policies occurred during the British colonial rule when part of the colonial effort was to encourage and direct farmers to increase agricultural production, mainly for the needs of Britain and also for local purposes. Organized agriculture in Nigeria can be traced back to 1893 when a department of Botanical Research was established with headquarters at Olokemeji in the former Western Nigeria (Williams, 1978; Akinbode, 1991). This marked a direct government involvement in the development of Agriculture. Notable achievements in the development of modern agriculture occurred when two departments of agriculture were created in 
southern and northern Nigeria in 1910 and 1912 (Forrest 1979; Williams 1978).

Another milestone in government involvement in the development of agriculture and perhaps, the first extension work in Nigeria was the establishment of the National Department of Agriculture in 1921, seven years after the amalgamation of the North and the South into a single political entity (Williams 1978; Ekpere, 1973). The main goals of the National Department were to increase export crops and set up and enforce laws and regulations on standards for the quality and quantity, marketing and handling of the major export crops; one of its objectives was also to establish the first elementary extension services. The establishment of a school of agriculture at Moor Plantation, Ibadan in the same year was in further recognition of the need for the training field-level extension workers.

Following five years of experimental work at Samaru, mixed farming (crop and Livestock) extension work began in 1927 in Kano and Zaria provinces (Forrest, 1979) but with negligible impact. Perhaps the major problem of the mixed farming extension work was its emphasis on the production of export crops, mainly cotton and groundnuts and its concern with mainly the traditional ruling class to whom farming was more of a hobby than an occupation. The development of agricultural extension in the 1930s was boosted by the establishment of a school of agriculture in the North in 1931 at Samaru, Zaria (Williams, 1978). Its major objective-was to train sub-professional staff (field-level extension workers) in modern agriculture. Unlike in Southern Nigeria, where provincial authorities were responsible for extension work, extension activities in the northern provinces rest mainly with the Native Authorities and involved village to village touring on horse-back or on foot and advising, encouraging and instructing farmers to integrate export crops into their farming system.

Also, specialized extension-extension work related to special agricultural projects, programmes or groups of farmers possibly started in the 1930s, with the onset of formal (government) supervision of agricultural Cooperative Societies in 1931. Before then, the Societies were loosely supervised by the Agricultural Department. In 1935 the Cooperative Societies Ordinance was passed and registered cooperative societies started to receive government recognition and financial assistance (Forrest, 1981). During 1940 - 1945 when import into Britain was restricted from other countries, Nigerian farmers were forced to grow export crops like cotton, cocoa, coffee and groundnuts to satisfy demand in the United Kingdom (Wudil, 1980). The colonial authorities also attempted to control production, movement and prices of foodstuffs and cash crops to minimize the anticipated post war shortages.

The 1940s and 1950s experienced another type of specialized extension in the form of rapid development of farm settlement schemes (Forrest, 1979), such as the Niger Agricultural project at Mokwa (1947), Shendam Scheme (1947) and Wawa Bush Project in the early 1950s. These schemes were to increase agricultural production, act as models to facilitate extension work in their locations and 
create positive demonstration effect on the catchment areas.

The 1950s experienced landmark development in agriculture and extension in Nigeria. The early part of the decade was a period of marked constitutional changes, leading to the creation of Regional Ministries of Agriculture and greater specialization of functions in these ministries. Thus, an extension or Field Service Division was one of the special units created in each regional ministry of agriculture, a development that marked the beginning of modern organization of agricultural extension. The organizational structure of extension services consisted of the region, Provinces, Divisions, Districts (or county councils in the case of the Eastern Region), Local Councils, Agricultural Areas and Villages. During this time, the previously applied British and Western European concept of extension which was tied to an extractive agricultural policy and operated by helping farmers increase production through regulation and service in the interest of the colonial government began to shift to the pattern of extension in the United States of America (Ekpere, 1973).

In Northern Nigeria, there was the cotton extension programme in Gombe and Gusau which coincided with attractive cotton prices and led to significant increases in yield. In western Nigeria where extension gave priority to government projects, cocoa spraying for capsid and black-pod disease resulted in substantial gains and in eastern Nigeria, there was considerable expansion of lowland rice production and milling in Ogoja and Onitsha provinces in the decade following the war (Forrest, 1979: p. 9).

\subsection{0-1970}

Following political independence in October 1960, there was some effort to increase foreign exchange earnings to sustain the newly independent nation. Thus, special agricultural and extension units such as Cocoa Development Unit (CDU) (e.g. Ikom Cocoa Estate),, Rubber Production Division (e.g. Pamol Nigeria Limited), Palm produce Division (e.g Borum, Calaro, Nsadop plantations), Groundnuts Division and Cotton were introduced to improve on the export crop earnings.

The unemployment problem of school leavers in the southern Nigeria in the 1960 s led to development of school leavers' farm project in the East, West and Mid-West. The project provided employment and contained rural-urban population drift, and served as models for facilitating extension work. The first (1962-68) and second (1970-1974) national development plans led to the establishment of National Accelerated Food Production Project (NAFPP).

\subsection{0s-1980}

The National Accelerated Food Production Project (NAFPP) of 1972 arose from the concern about research findings not reaching farmers at all, or reaching them late, and/ or in the form that is not easily useful to them (Akinbode, 1991). The third Development Plan of 1975 to 80 then came with: 
1) Agricultural Development Projects (ADPs) which were setup in various parts of the country starting from 1974 - 1975. Partly financed by the World Bank, these projects were to promote integrated rural development by providing facilities for intensive extension services, modern input supplies and distribution system and rural infrastructures, especially feeder roads.

2) Livestock Development Projects which were started in 1976 to commercialize beef production by establishment of large scale public breeding ranches to encourage small-scale private ranches, development of grazing reserves and provision of supervised credit for small holder fattening schemes.

3) River Basin Development Authorities that also started in 1976 for the purpose of facilitating irrigation, fishery development, control of flood, water pollution and control erosion. Policy instruments include input distribution, credit services, infrastructure development, manpower development, etc.

4) Operation Feed the Nation (OFN), which started on $21^{\text {st }}$ May, 1976, was aimed at curtailing massive food importation to the country. The objectives were to meet the acute shortage in food supply, and restore some respectability to farming with the view to minimizing the movement of youths from the rural area to the cities. Urban dwellers were also encouraged, through the programme, to engage in backyard farming. The operations also attempted raising production and productivity by distributing inorganic fertilizers and improved seeds/seedlings.

5) Agricultural Credit Guarantee Scheme was set up in 1976, under the Central Bank of Nigeria to mobilize funds from the banking sector for rural development to guarantee loans by the commercial banks for investment in agriculture to minimize the risk involved in financing the sector. The implementation of this policy has been too slow to reach all interested farmers.

6) The Land use Act of 1976 was meant to facilitate an effective utilization and exploitation of land resources for agricultural purposes. The law sought to bring the existing land tenure system under one common law. However, this law has been largely abused as public officials with authority for land use approval have expropriated large portions for self-based compromises. Besides the law has become a key bottleneck to land access and alienation for investment uses, necessitating the call for its amendment.

\subsection{0-1985}

The Green Revolution was launched in 1980 by the Shagari regime as essentially a reformation of Operation Feed the Nation Programme but focused on the small farmer and the development of the rural areas. It aimed to address agricultural production from a fully mechanized and capacity upgrading perspective. To this effect, the government supported the policy with deliberate program of procuring machineries for fully mechanized farming. It also established the Universities of Agriculture to enhance the nurturing of a young, educated population of modern farmers learned in mechanized production. 
In 1986, the Directorate of Food, Roads and Rural infrastructure (GSRRI) was established by the Babangida regime. The objective was to facilitate roads and rural infrastructure programmes and provide rural infrastructure. The Better Life Programme (BLP) was introduced in 1987 to inculcate the spirit of self-development, particularly in education, business, arts, crafts, and agriculture. Also, it aimed to raise consciousness about rights, opportunities and facilitate political and economic responsibilities.

\subsection{0-2016}

The policies during this time frame included:

1) Community Banking Programme 1990.

2) National Agricultural Development Land Authority (NALDA) 1991.

3) Family Support Programme 1992.

4) Family Economic Advancement Programme (FEAP) 1994.

5) Fadama Development Project 1996.

6) National Special Programme for Food Security (NSPFS) 2001. This NSPFS policy brought about the:

a) Special Programme for Food Security (SPFF) 2002.

b) Root and Tuber Expansion Programme (1999).

c) Community-based Agricultural and Rural Development Scheme (2001).

i) The establishment of National Economic Empowerment Development Strategy (NEEDS) in 1999.

ii) The establishment of Medium Term Strategic Sector (MTSSS) 2001.

iii) Commercial Agriculture Development Agency (CADA) 2006.

iv) Growth Enhancement Support Scheme (GES) 2011.

v) Agricultural Transformation Agenda (AGA) 2012.

vi) Central Bank of Nigeria Anchor Borrowers's scheme of 2016.

\section{Limitations to the Effectiveness of Agricultural Policies in Nigeria}

\section{1) Policy instability}

The rate of turnover of agricultural policies has been high, with many policies formulated and scrapped in rapid succession. This problem could be partly ascribed to political instability, as successive governments have tended to jettison most of their ' policies and programs in the erroneous belief that a new government could only justify its existence or make its mark by adopting entirely new policies and programs.

\section{2) Inconsistency in policies}

Some agricultural policies and programs often seem to be mutually antagonistic rather than being complementary and reinforcing. A popular example is the conflict between Government's domestic food production policy and its cheap food import policy. The latter was so antagonistic of the former as to render it ineffective. Fundamental key reason for the policy inconsistency is the failure of 
policy makers to adopt a systems approach to policy formulation. A systems approach is that which the entire spectrum of agricultural and rural development problems are viewed globally so that consistent, mutually reinforcing policies could be addressed to them.

\section{3) Narrow base of policy formulation}

The base of the agricultural policy formulation process in Nigeria is rather narrow because the level of involvement of the people and their institutions in the formulation of policies affecting their lives was minimal. In the circumstance, these policies tended to lack grass root support and the popular mobilization required for their success.

\section{4) Poor implementation of policies}

Quite often, the formulation of policies seems to be considered as ends in themselves, rather than as means to desired ends. Thus, little attention is paid to the efficient implementation of policies. Bureaucrats and policy implementers tend to lose sight of the fundamental objectives of policies, instead, focusing on superficial issues. Poor managerial capacity, bureaucratic problems, corruption, and high rates of policy turnover tended to complicate the problem of policy implementation.

\section{5) Weak institutional framework for policy coordination}

The typically weak institutional arrangements for policy and program coordination often leads to duplication of effort and general inefficiency in resource use among agencies and ministries even in the same government, between federal and state agencies, and between states. There is also weak monitoring and evaluation arrangements for policy implementation, leading to situations in which policies and programs tended to miss their intended goals without corrective measures being taken.

\section{6) Top-Bottom Approach}

This approach to policy implementation has adversely affected agricultural policies; a bottom-top approach in policy formulation implementation should be preferred.

\section{Nigeria's Food/Agriculture Security Policy and the Role of Science-Technology and Innovation in Food Security}

In the 1940s and early 50s, Nigeria had little issues with food insecurity as the system adequately fed her citizens and even exported surplus food items. Every region of the country specialized in the production of one or two major crops, whether food or cash crops, and together the country was relatively self-sufficient in food production. However, the discovery of crude oil in 1956 and its exportation in 1958, changed the situation significantly. As oil prices went up, interest in agriculture, marking the beginning of the decline in agricultural output.

The resulting effect was the rising cost of food items, especially the rise in the prices of staple foods. Significantly, the price of rice has increased by over 100 
per cent since 2006. Nigeria requires 2.5 million metric tons of rice annually but local production is less than half a million metric tons per year. Thus, Nigeria has a deficit of two million tons of rice, which it has to source from other countries. Nigeria spends a whopping $\$ 2$ billion dollars importing about six million tons of wheat, $\$ 750$ million on rice, $\$ 700$ million on sugar and $\$ 500$ million on milk and other dairy products. The rapid rise in food prices would be most acutely felt by vulnerable households, where difficulties in accessing cereals would lead to localized food security problems.

Apart from the high prices of staple food items, drought and political situation in neighboring countries like Chad, Cameroun and Niger are a threat to border states like Borno and Adamawa, as they rely on these states for their food supplies. Another cause of the food crisis in Nigeria is the near total reliance on rain-fed agriculture without taking full advantage of the irrigation potential estimated at 2.0 to 2.5 million hectares. The area under irrigation is officially estimated at about 220,000 hectares or less than a per cent of the total area under crops.

In contrast, while drought presents a major problem for the affordability and availability of food items, excessive rainfall has also contributed significantly to the current hike in food prices. For example, statistics from Gombe State alone show that about 999 farmlands were affected by floods which frequently destroyed yams, maize, vegetable, sugarcane and cassava farms. In Cross River State, about 15,000 were affected in 2012 farming season. When data from other states are added the ripple effect becomes staggering.

At present, climate change conditions favor the rising food prices; deficiencies in the delivery of farm inputs also constitute a major challenge to farmers. Another factor is the low usage of fertilizers resulting in low crop yield; the current fertilizer use is only about $15 \mathrm{~kg} / \mathrm{ha}$ compared to the world average of 100 $\mathrm{kg} / \mathrm{ha}$ NPK.

There is considerable difference between food policy and agricultural policy. Whereas agricultural policy is targeted at an expanded food production, food policy has consideration for minimum nutritional standards that will guarantee food security. It is necessary to have expansive agricultural policy but there is also the need for a national food policy which seeks to assure all citizens access to food supply that is reasonably priced, relatively safe and adequate in quantity and quality (Claffey \& Stucker, 1982; Nyangito, 1999).

At present, Nigeria has no food policy possibly because there is little appreciation of its contemporary role in agricultural system and practices to promote relative self-sufficiency in food production. A food policy properly formulated will encompass diet policy that shows for example, the relationship between good diet and good living as well as causal link between inappropriate or insufficient/unbalanced diet and major and common debilitating diseases. With the current knowledge of human nutrition, a food policy will be guided by what the human body requires and which particular food items provide it, all of which are 
pre-requisites for effective food choices by the people.

Unlike agricultural policy, a food policy should stipulate safety guidelines for food production in the growing food industry. This should lead to food safety regulations such as the minimum requirements of basic nutrients that must be present in the food, the conditions under which the food is produced, its packaging and even the advertisement to promote the consumption of the food. Similarly, safety guidelines embedded in food policy should prohibit very harmful practices that may occur in the dairy industry, meat processing factories, as well as the use of carcinogenic food additives and food enhancers that are routinely used by bakers to preserve food or improve its taste (Davies, 2009).

Pesticides, therapeutic drugs and chronically compounded feeds for crop production and improved nutrition for livestock are some of the inputs which experts in agriculture regularly advise and encourage farmers to use while the government sometimes makes them available at subsidized price. But the manufacture, distribution and application of these agro-chemicals can hardly be effectively monitored or controlled without first formulating a good food policy that incorporates safety concerns (Oniang'o \& Allotey, 1989). Thus the goal of food security will remain unattainable if all that matters to the government is simply making food available in the quantity desired by the people but its consumption is capable of causing the consumers all sorts of ailments. Such people cannot be listed among those that have achieved food security. To avoid this situation, the National Food and Drug Administration and Control (NAFDAC) was established. However, much as this agency is working hard to be effective in preventing food poisoning and fake drugs, it has not been able to achieve much because:

1) Its operational emphasis and laboratory facilities has been in ridding the country of fake, substandard and expired drugs, manufactured in or imported into the country.

2) It has not proactive enough in monitoring production, sale and distribution of foods as it tirelessly and commendably does on fake and expired drugs; and

3) Its activities duplicate those of the Standard organization of Nigeria (SON), another regulatory agency, empowered to set standard for all consumer products, including food, drugs, cosmetics, tyres, cables, etc.

Environmental degradation has long been identified as one of the reasons for poor agricultural production (Collier, 1988). Indigenous techniques like crop rotation and other cultural farming practices which have been used to preserve the soil structure and fertility do not seem to be adequate, or even relevant in the present efforts to boost food production in Nigeria. Thus, the use of inorganic and organic fertilizer has been widely promoted with heavy subsidies from the State, although corruption is associated with its procurement and distribution (Idachaba, 2004). Government has also intervened to increase food production through technical and economic assistance to the small-scale farmers for land improvement. The threat to food security in Nigeria also emanates from the unresolved issue of the safety of genetically modified foods, resulting from agricul- 
tural biotechnology. Biotechnology is a scientific advance in agriculture with far reaching potentials for increasing food production in an environmentally sustainable manner. Agricultural biotechnology involves using genetic approaches to modify crops and plants to produce more nutritious food, cloning of livestock, tissue culture technique and genetic engineering. Genetic engineering confers shorter gestation and maturity periods on crops and livestock. Parts of these foods are sold and sometimes given as food aid to developing countries, despite safety concerns raised by some anti-biotechnology campaigners in EU countries against genetically modified foods.

Nigerian government has embraced the idea of using biotechnology to boost food production as a pre-condition for food security. Thus, the National Biotechnology Development Agency at Abuja (Federal Capital Territory) was established while the Institute of Agricultural Research, Ahmadu Bello University, Zaria, was mandated to apply biotechnology for the improvement of farming systems for various crops such as Sorghum, maize, cowpea, cotton and sunflower.

Furthermore, Nigerian agricultural scientists have been very enthusiastic in advancing the frontier of knowledge in biotechnology. Efforts have been made to assure the people that genetically modified foods do not pose any higher risk to consumers than conventionally cultivated crops. There have been calls on the government to allocate more research funds to enhance the application of biotechnology in agriculture to optimize yield potentials (Akinyosove, 2007).

However, there are still obstacles to full adoption of biotechnological approaches in agriculture. First, the budget for investment in the project is grossly inadequate. There is need to invite the private sector participation in biotechnology research as the government seems to be doing all the moment; most of the companies with the financial capability to go into such venture are foreign-owned and are not likely to consider an investment into purely local agricultural research endeavor a viable venture.

Also, the quality and the effectiveness of extension services needed to increase the awareness of the peasant farmers of the potentials of biotechnology are still low and need to be upgraded. The mass media, most especially, electronic media (radio in particular) have a role to play in educating rural farmers through extension system in their local languages and dialects on the associated problems, vis-a-vis abuse of agro-chemicals. Most importantly, the unwarranted public fears in the safety of genetically modified foods, stemming from scare-stories, reinforced by superstition and crash ignorance, of the danger in the consumption of genetically modified foods need to be addressed. What is certain however, is that without the help of agricultural biotechnology, success in food security will continue to elude Nigeria (Davies, 2009).

\section{Roles and Responsibilities of Stakeholders}

Nigeria's recent agricultural policy has defined specific roles and responsibilities for the federal, state and local governments as well as the private sector to avoid 
role duplication and overlapping functions amongst them. The revised roles and responsibilities are aimed at realizing full policy implementation and synergy at each level of government as follows:

\section{1) The Federal Government}

Under the new policy regime, the Federal Government shall be responsible for (i) the provision of a general policy framework including macroeconomic policies for agricultural and rural development and for the guidance of all stakeholders; (ii) maintenance of a reasonable flow of resources into agriculture and the rural economy; (iii) support for rural infrastructure development in collaboration with state and local governments; (iv) research and development of appropriate technology for agriculture, including biotechnology; (v) seed industry development, seed law enforcement, and seed quality control; (vi) support for input supply and distribution, including seeds, seedlings, brood stock, and fingerlings; (vii) continued support for agricultural extension services; (viii) management of impounded water, supervision of large dams and irrigation canals, and maintenance of pumping facilities; (ix) control of pests and diseases of national and international significance and the promotion of integrated disease and pest management; ( $\mathrm{x}$ ) establishment and maintenance of virile national and international animal and plant quarantine services; (xi) maintenance of a favorable tariff regime for agricultural commodities; (xii) promotion of the export of agricultural commodities through, among others, the Export Processing Zones (EPZs);(xiii) establishment of an agricultural insurance scheme; (xiv) maintenance of a Strategic National Grain Reserve for national food security; (xv) coordination of agricultural data and information management systems; (xvi) inventory of land resources and control of land use and land degradation; (xvii) training and manpower development; (xviii) participation in the mapping and development of interstate cattle and grazing routes and watering points; (xix) promotion of micro- and rural credit institutions; (xx) promotion of agricultural commodity development and marketing institutions; (xxi) maintenance of fishing terminals and other fisheries infrastructure, including cold rooms; (xxii) promotion of trawling, artisanal, and aquaculture fisheries; (xxiii) promotion of fish feed production; (xxiv) protection of Nigeria's Exclusive Economic Zone for fisheries resources; and (xxv) periodic review of agreements on international agricultural trade.

\section{2) The State Government}

The state governments are primarily responsible for (i) the promotion of the primary production of all agricultural commodities through the provision of a virile and effective extension service; (ii) promotion of the production of inputs for crops, livestock, fish, and forestry; (iii) ensuring access to land for all those wishing to engage in farming; (iv) development and management of irrigation facilities and dams; (v) grazing reserve development and creation of water access for livestock; (vi) training and manpower development; (vii) control of plant and animal pests and diseases; (viii) promotion of appropriate institutions for admi- 
nistering credit to smallholder farmers; (ix) maintenance of buffer stocks of agricultural commodities; $(\mathrm{x})$ investment in rural infrastructure including rural roads and water supply in collaboration with federal and local governments; and (xi) ownership, management, and control of forest estates held in trust for local communities.

\section{3) Local governments}

The local governments are expected to take over progressively the responsibilities of state governments with respect to (i) the provision of an effective extension service; (ii) provision of rural infrastructure to complement federal and state governments' efforts; (iii) management of irrigation areas of dams; (iv) mobilization of farmers for accelerated agricultural and rural development through cooperative organizations, local institutions, and communities; (v) provision of land for new entrants into farming in accordance with the provision of the Land Use Act; and (vi) coordination of data collection at primary levels.

\section{4) The Private Sector}

According to the policy document, since agricultural production, processing, storage, and marketing are essentially private sector activities, the role of the private sector will be to take advantage of the improved enabling environment provided by the public sector for profitable agricultural investment. In particular, the private sector is expected to play a leading role with respect to (i) investment in all aspects of upstream and downstream agricultural enterprises and agribusinesses, including agricultural commodity storage, processing, and marketing; (ii) agricultural input supply and distribution; (iii) the production of commercial seeds, seedlings, brood stock, and fingerlings under government certification and quality control; (iv) agricultural mechanization; (v) provision of enterprise-specific rural infrastructure; and (vi) support for research in all aspects of agriculture.

The missing link in past agricultural policies and initiatives has been the private sector involvement. Private sector has been identified as the engine needed to stimulate agricultural growth by investing in large scale agricultural production, processing, marketing and overall commercialization. However, the private sector is faced with militating factors to drive the agricultural sector. Among the factors limiting the performance of the private sector in agriculture are:

- Inadequate capacity to discharge the anticipated agricultural services;

- Limited long-term financing at affordable interest rate;

- Un-conducive taxation system;

- Cumbersome procedures for accessing land and business licensing;

- communication network;

- Low knowhow.

\section{Policies for Service Delivery}

\subsection{Extension Services Policy}

Agricultural extension services, is important support service required for the 
development of the agricultural sector. It provides the critical support to farmers in terms of education and information required for them to improve their farms and livelihood. The policy on extension is therefore important in order to provide farmers with the requisite skills and knowledge required for them to remain competitive in this modern world. The State Extension Services policy aims to:

- Assist farmers increase production and productivity;

- Ensure farmers get information on production, marketing and other support services required for the development of agriculture in the state;

- Ensure that farmers adhere to Good Agricultural Practices (GAP) by impacting the right knowledge and skills required by farmers in the state;

- Increase participation of the private sector in the extension delivery service;

- Increase the linkage between research-extension-farmers, so that new ideas are promptly disseminated to farmers.

Problems

- Lack of adequate staff to undertake extension services across the state;

- Poor linkages between Research, Extension and the farmers resulting in the development of inappropriate technology;

- Extension strategy remains basically top-down with little input from farmers;

- Weak supervision and coordination of extension activities in the state;

- Poor remuneration of staff and insufficient funding of extension activities;

- Lack of private sector participation in extension activities.

Strategies

To seriously address the above problems, there is need to:

- Reorganize and reform the extension service so that farmers can get quality service;

- Encourage the involvement of the private sector in extension to increase funding and improve service delivery;

- Employ and train more Extension Officers to increase their area of coverage for effective delivery across the state;

- Strengthen farmer education and publicity for effective linkage and dissemination of information;

- Government should implement integrated rural development in areas with difficult terrain in order to allow extension workers penetrate and disseminate information in those areas to raise the quality of life of the people;

- Provide better working conditions for extension workers to motivate and encourage them to work better;

- Government should increase supervision of extension workers in the field and ensure that they adhere to international performance standard;

- Encourage participatory approach to extension, so that farmers would feel they are part of the system for sustainability;

- Clearly define the roles of the different stakeholders in extension service, especially the role of Local Government Councils to prevent conflict and allow for better service delivery. 


\subsection{Agriculture Mechanization and Irrigation Development Policy}

One of the major challenges to agricultural development in Nigeria is the low level of utilization of farm machinery as most farmers still use hand hoe for soil preparation. Also, very few farmers practice irrigation. The lack of irrigated farms reduces farmer's crop yield, since they cannot not cultivate than once a year. The Mechanization and Irrigation Development Policy aims to:

- Facilitate access to mechanized and irrigation equipment at affordable prices;

- Facilitate access of agricultural processors to mechanized equipment;

- Ensure the efficient use of farm equipment and agro processing machines;

- Develop human capacity in the management, operation and maintenance of agricultural equipment;

- Facilitate the adoption of irrigation to enhance productivity;

- Eensure increased private sector participation in agricultural mechanization and irrigation.

\section{Problems}

- Inadequate number of agricultural machinery vendors;

- High cost of mechanization machinery and irrigation equipment;

- Inadequate private sector participation in agricultural mechanization schemes;

- Inadequate trained operators for the operation and maintenance of the machineries and equipment.

Strategies

Strategies that should be adopted by the government in implementing mechanization and irrigation policies include:

- Sensitization of investors on simple processes and technologies for agricultural production to increase awareness;

- Provide incentives and conducive environment or private sector involvement $\mathrm{n}$ mechanization and irrigation in agriculture in the state;

- Sensitization and promotion of the use of simple farm machines and equipment by small scale farmers in the state;

- Provide access to long-term finance for the acquisition of these machineries and irrigation equipment;

- In collaboration with the universities and private sector arrange training programmes for the maintenance and operation of these machines;

- Promote private sector participation in the development of agricultural mechanization and irrigation schemes in the state through fabrication of simple specialized equipment for the agricultural sector;

- Collaboration with Basin Development Authority and the Federal Ministry of Water Resources for the construction of dams and irrigation facilities in some parts of the state.

\subsection{Agricultural Inputs Supply Development Policy}

Access to agricultural inputs like fertilizer, agrochemicals, seeds, farm implements and others, is critical for achieving self-sufficiency in agricultural produc- 
tion, in reducing rural poverty and meeting the important goal of food security for the state. This policy will therefore ensure and promote private sector participation in this critical sub-sector to ensure long-term sustainability.

The goals of the State Agricultural Inputs Supply Development Policy are:

- To facilitate access of our farmers to critical agricultural inputs at affordable prices;

- To create employment opportunities for youths by engaging them as agro dealers in their respective areas;

- To ensure the increase and efficient use of agro chemicals in the state;

- To promote the development of agro-input manufacturing and marketing industry in the state;

- To promote the development of human capacity in the management of input supply in the state;

- To ensure increase private sector participation in the inputs supply sub-sector. Problems:

- Inadequate number of agricultural input vendors;

- High cost of most agricultural inputs which cannot be afforded by our farmers;

- Inadequate private sector participation in agricultural inputs manufacturing and distribution, especially in their areas of seed production and breed multiplication;

- Inadequate inputs manufacturing firms in the state;

- Non-existence quality control mechanism for monitoring the inputs sub-sector. Strategies

Strategies to be adopted by the government in implementing the agricultural inputs supply development policies are:

- Sensitize and promote the participation of the private sector in the manufacturing and distribution of inputs in the state;

- Provide incentives and conducive environment for private sector involvement in the sub-sector;

- Sensitization and promotion of the use of inputs like fertilizer, seeds and others by smallholder farmers in the state;

- Provide support to farmers to access inputs through government subsidy;

- Provide access to long-term finance for the manufacturers and agro dealers;

- Collaborate with Federal Ministry of Agriculture and Rural Development (FMARD) to monitor the supply of inputs to prevent farmers for getting adulterated inputs.

\subsection{Cross Cutting Policies}

\section{Environmental Strategy}

The State Government will aim at mainstreaming and Promoting the scaling up of sustainable land management (SLM) practices in addressing objectives around both environmental resilience and agricultural productivity in line with 
the country's overall development agenda. In additional to addressing issues (barriers or opportunities) of productivity in both agriculture and in environmental issues, this objective will serve as entry point in addressing the interactions between agriculture and climate change and biodiversity loss. Sustainable agricultural practice as well as sustainable forest management can help address climate change.

Strategic Environmental plan of the Cross River Sate Government will ensure that the policy is consistent with all national, regional and sub-regional approaches on sustainable natural resource management. Inclusiveness and cross-sector interactions will guide the implementation of strategies designed to achieve this objective.

Issues

- Sustainable land and water management are not adequately integrated as part of agricultural extension services.

- High environmental degradation and abuse due to inadequate understanding of environmental issues related to agriculture.

- Lack of national agricultural land use policy.

- Ineffective framework for collaboration with appropriate agencies to address environmental issues related to agriculture.

- Climate change is a serious environmental threat; Agriculture is sensitive to changes in climate.

Strategies

- Mainstream sustainable land and environmental management practices in agricultural sector planning and implementation.

- Create awareness about environmental issues among all stakeholders and develop an effective and efficient framework for collaboration with appropriate agencies to ensure environmental compliance.

- Adopt an integrated approach in dealing with environmental issues, including an inclusive partnership-based coordinated approach with active and mutual involvement of NGOs and Civil Society Organizations, the Private Sector and the Development Partners.

- Improve incentive and compulsion measures to encourage users of the environment to adopt less exploitative and non-degrading practices in agriculture.

- Promote joint planning and implementation of programmes with relevant institutions to address environmental issues in food and agriculture.

- Promote the development of community land use plans and enforce their use, particularly in urban and sub-urban agriculture.

- Improve access of operators in urban agriculture to sustainable land and environmental management practices.

- Stimulate, support and facilitate adaptation and widespread adoption of farming and land use practices which, while in harmony with natural resource resilience, also underpin viable and sustainable production levels. 


\subsection{Human Capital Development Strategy}

The basic aim of this strategy is targeted towards a modernized agriculture in which productivity and production improvements are based on science and technology. Prioritization of research on the basis of commodities targeted in Cross River State and public funding of basic research will guide the promotion of science and technology in agricultural development. Demand-driven research implies the activity is motivated from the desires of final users (beneficiaries). Issues:

- Low uptake of research findings by stakeholders;

- Often there is duplication of functions;

- Inadequate capacity building;

- Funding and commitment to agricultural research;

- Limited application of biotechnology and its benefits;

- Limited agricultural policy research;

- Limited research on industrial uses of indigenous crops and livestock;

- Absence of up-to-date data /statistics on women farmers, particularly poor women farmers, to inform policy making and programming;

- Most agricultural research is not designed from a gender perspective. Strategies:

- High priority will be given to "applied research" with more research initiatives being redirected towards supporting on-farm and off-farm innovations for improved production systems, higher productivity and small/large scale industrialisation/processing.

- Cross River State will partner with the National Agriculture Research Institutes to ensure that research focuses on the human capital development and development of value chain of commodities targeted for food security, wealth creation and diversification, external markets, and linkage with industry.

- Best practices of land and environmental management will be applied. Specific measures are:

- The Government will endeavour to improve the uptake of technologies by improving relevance of technologies to users and their access to the technologies.

- Promote demand-driven projects.

- Improve the effectiveness of Research-Extension-Farmer Linkages (REFLs) and integrate the concept into the agricultural research system to increase participation of end users in technology development.

- Gender considerations will be integrated in programmes.

- Promote coordination and collaboration between local and foreign Research Institutions to improve cost-effectiveness of research.

- Ensure sustained funding of research by partnering with the private sector (including farmer groups) and NGOs to identify and adopt innovative approaches to agricultural research funding and commercialization.

- Facilitate the passage of the bio-safety bill, to improve food safety and to pave 
the way for use of biotechnology tools in crop and livestock improvement research.

- Intensify and advocate for increased capacity building for socioeconomic development.

- Promote research in the development and industrial use of indigenous staples and livestock.

\section{Conclusion}

Nigeria's agricultural policy framework has evolved in a way that reflected, in a historical perspective, the changing character of agricultural development problems and the roles which different segments of the society were expected to play in addressing these problems. The form and direction of agricultural policy were dictated by the philosophical stance of government on the content of agricultural development and the role of government in the development process.

One of the major objectives Nigeria must pursue now is food security. A country that is unable to formulate and effectively implement agricultural and food policies may find it difficult to use its citizens as catalyst for sustainable development. The very survival of Nigeria is tied to the ability of its economy to meet the material demands of its citizens since welfare constitutes a third objective of modern government. This is a fact comparable to their common pursuit of national economic health. Food is an essential component of welfarism. The Nigerian Government and public policy makers must as a matter of urgency see food as a component of welfarism and as such develop sufficient political will to achieve 1) increased food production; 2) evolved food policy and 3) eventually attaining food security for all.

\section{Conflicts of Interest}

The authors declare no conflicts of interest regarding the publication of this paper.

\section{References}

Akinbode, I.A. (1991). Women's Participation in Agriculture in Nigeria: A Case Study of Ogun, Gangola, cross River, Kano and Niger States. Nigeria: Food and Agriculture Organization of the United Nations/Federal Department of Agriculture.

Claffey, B., \& Stucker, T. (1982). Food Stamp Program. In D. Hadwiger, \& R. Talbot (Eds.), Food Policy and Farm Programs (Vol. 34, pp. 40-53). New York: The Academy of Political Science. https://doi.org/10.2307/1173727

Collier, P. (1988). Oil Shock and Food Security in Nigeria. International Labour Review, $127,761$.

Davies, E. A. (2009). Food Security Initiatives in Nigeria: Prospects and Challenges. Journal of Sustainable Development in Africa, 11.

Ekpere, J. A. (1973). Organisation Structure, Environment, Performance: The Role of Strategic Choice. Sociology, 6, 1-22.

Forrest, T. (1981). Agricultural Policies in Nigeria 1900-78. In J. Heyer, P. Roberts, \& G. Williams (Eds.), Rural Development in Tropical Africa (pp. 222-258). London: Pal- 
grave Macmillan. https://doi.org/10.1007/978-1-349-05318-6_9

Idachaba, F. S. (2004). Food Security in Nigeria: Challenges under Democratic Dispensation. In 9th ARMTI Annual Lecture.

Nyangito, H. (1999). Agricultural Sector Performance in a Changing Policy Environment In P. Kimuyu, M. Wagacha, \& O. Abagi (Eds.), Kenya's Strategic Policies for 21st Century (pp. 129-164). Nairobi, Kenya: Institute of Policy Analysis and Research (IPAR).

Olagunju, A. (2007) Water Resources Development: Opportunities for Increased Agricultural Production in Nigeria. Unpublished Master's Thesis, Linkoping University.

Oniang'o, R., \& Allotey, J. (1989). Food Safety and the Role of Government. In A. Ogunrinde, R. Oniang'o, \& J. May (Eds.), Not by Bread Alone: Food Security and Governance. South Africa: 2009 Institute for Global Peace and Policy Research.

Sanni, A. (2010). Opportunities for Investment in Cassava, Rice and Sorghum. In Conference on Boosting the Nigerian Agricultural Sector through Financing, Processing and Capacity Building organized by USAID on Trade on Development (115 p). Lagos, Nigeria: USAID.

Shinka, J. (2009). Supporting Commercial Agriculture in Nigeria: Opportunities for Production and Processing Investment. In Conference on Boosting the Nigerian Agricultural Sector through Financing, Processing and Capacity Building organized by USAID on Trade on Development (115 p). Lagos, Nigeria: USAID.

United Nations Development Programme (2001). Human Development Report 2000/2001 Millennium Edition. UNDP: Lagos. https://doi.org/10.18356/2e565da3-en

Uzor, E. (2010). Positioning Agriculture for National Development. Zenith Economic Quarterly, 4, 34-37.

Williams, S. K. T. (1978). Rural Development in Nigeria. Ile-Ife, Nigeria: University of Ife Press.

Wudil, J. (1980). Problems of Extension Workers in Nigeria. In Nigerian Agricultural EXtension Conference (298 p) Zaria: Agricultural Extension and Liaison Services. 